\title{
FACTORS AFFECTING CONVERSION OF LAPAROSCOPIC CHOLECYSTECTOMY TO OPEN SURGERY IN A TERTIARY HOSPITAL IN SOUTH INDIA
}

\author{
N. Suresh Kumar', R. Balamuragan², Mohamed Zakkaria ${ }^{3}$
}

1 Associate Professor, Department of General Surgery, SRM Medical College Hospital \& Research Centre, Kattankulathur, Chennai. ${ }^{2}$ Associate Professor, Department of General Surgery, SRM Medical College Hospital \& Research Centre, Kattankulathur, Chennai. ${ }^{3}$ Post Graduate, Department of General Surgery, SRM Medical College Hospital \& Research Centre, Kattankulathur, Chennai.

\section{ABSTRACT}

\section{BACKGROUND}

Laparoscopic Cholecystectomy (LC) is most commonly performed hepatobiliary minimally access surgery worldwide. Laparoscopic cholecystectomy has become the standard treatment for symptomatic gallstone diseases. However, there still is a substantial proportion of patients in whom laparoscopic cholecystectomy cannot be successfully performed and for whom conversion to open surgery is required. The NIH postulated that the outcome of LCs would be greatly influenced by surgeon-specific factors such as training, experience, skill and judgment.(1) In addition numerous patient and disease-related factors, such as male gender, obesity, old age (>65), prior abdominal surgery, acute cholecystitis, choledocholithiasis and anomalous anatomy have been reported as significant risk factors for conversion to the open procedure.(2-5)

Although the rate of conversion to open surgery and the complication rate are low in experienced hands, the surgeon should not enter the Operating Room with idea of opening the abdomen in difficult case as failure or insult to the surgeon. Various preoperative factors can help in deciding the difficult gallbladder and conversion to open cholecystectomy. The aim of this study is to predict the difficulty of laparoscopic cholecystectomy and the possibility of conversion to open cholecystectomy before and during surgery using the clinical and ultrasonographic criteria in our setup.

\section{MATERIALS AND METHODS}

A prospective study was performed in SRM Medical College and Hospital of all patients who underwent LC during (May 2013 to October 2015) was performed. The LCs were performed by 12 trained certified surgeons. The decision to convert to open was made by the individual surgeon and the reason for conversion was extracted from the patient's medical record (operative report) prospectively. The inclusion and exclusion criteria defined. All operations were performed with the patient under general anesthesia with endotracheal intubation using either a 3- or 4-trocar technique.

\section{RESULTS}

Females were the main sufferers of gallbladder disease in our study. There was a preponderance of cases in the $3^{\text {rd }}$ and $4^{\text {th }}$ decades of life. Most of the patients presented with the chief complaint of pain abdomen in the right hypochondrium. The mean operation time was 81.7 minutes and the average length of post-operative hospital stay was 3.6 days. Among a total of 36 male patients, 5 were converted (13.8\%), whereas among 46 Female patients, 7 were converted (15.2\%).

Out of 112 patients studied, 12 cases were converted to open cholecystectomy, i.e. $10.7 \%$. Conversion was more common in diabetic patients. The main intra-operative cause of conversion from laparoscopic cholecystectomy to open was difficulty in identifying the anatomy as a result of dense adhesions followed by hemorrhage in the Calot's triangle and non-visualization of junction of cystic duct with CBD and possible injury to the CBD. Anyhow no, post-operative CBD injury occurred.

\section{KEYWORDS}

Laparoscopic Cholecystectomy, Open, Conversion.

HOW TO CITE THIS ARTICLE: Kumar NS, Balamuragan R, Zakkaria M. Factors affecting conversion of laparoscopic cholecystectomy to open surgery in a tertiary hospital in South India. J Evolution Med Dent Sci 2016;5(4):256-261,

DOI: $10.14260 /$ jemds/2016/54

\section{METHODOLOGY}

\section{Source of Data}

All patients undergoing laparoscopic cholecystectomy at SRM Medical College and Hospital from May 2013 to Oct 2015 and includes 112 patients. This is a prospective study conducted over 2.5 years.

Financial or Other, Competing Interest: None.

Submission 30-11-2015, Peer Review 01-12-2015,

Acceptance 14-12-2015, Published 13-01-2016.

Corresponding Author:

Dr. N. Suresh Kumar,

Associate Professor,

Department of General Surgery,

SRM Medical College Hospital \& Research Centre,

Kattankulathur,

Chennai-603203.

E-mail:nagansuresh@gmail.com

DOI:10.14260/jemds/2016/54

\section{Methods of Collection of Data}

All patients presenting with cholelithiasis without choledocholithiasis and with no contraindication for general anesthesia were included in the study. Medical records of all patients who underwent LC were reviewed. Data recorded included demographic information, past medical history, indication for operation, duration of operation, reason for conversion and post-operative complications.

\section{Inclusion Criteria}

- All patients with symptomatic cholelithiasis (Including acute cholecystitis).

- Patients presenting with acalculous cholecystitis.

- Age $>18$ years. 


\section{Exclusion Criteria}

- Carcinoma of Gallbladder.

- Perforated Gallbladder.

- Patients unfit for general anesthesia.

- Previous upper abdominal surgery.

- Age $<18$ years.

\section{RESULTS}

\section{Age Incidence}

The mean age in this study was 43.4 years. The age group of the patients ranged from 21 years to 79 years. The maximum incidence is seen in the age group of 41-50 years followed by 31-40 years of age; $75 \%$ of patients belonged to ages between 31 and 60 (Table 1) and (Figure 1).

\begin{tabular}{|c|c|c|}
\hline $\begin{array}{c}\text { Age } \\
\text { Group }\end{array}$ & $\begin{array}{c}\text { No. of } \\
\text { Patients }\end{array}$ & $\begin{array}{c}\text { Percentage } \\
\text { (\%) }\end{array}$ \\
\hline $21-30$ & 19 & $16.9 \%$ \\
\hline $31-40$ & 30 & $26.7 \%$ \\
\hline $41-50$ & 34 & $30.3 \%$ \\
\hline $51-60$ & 21 & $18.7 \%$ \\
\hline $61-70$ & 6 & $5.3 \%$ \\
\hline $71-80$ & 2 & $1.7 \%$ \\
\hline \multicolumn{3}{|c|}{ Table 1: Age Incidence } \\
\hline
\end{tabular}

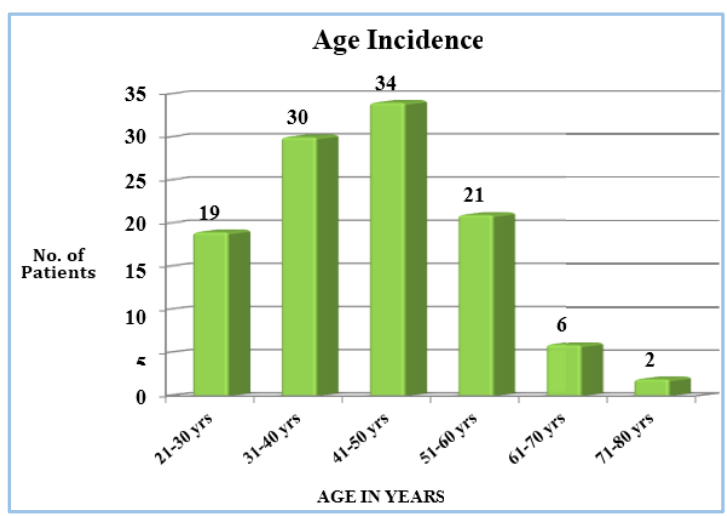

Fig. 1: Graphical representation of age incidence

\section{Sex Incidence}

In 100 cases, 32 were males and 68 were females. The ratio of male-to-female 1:2. The above sex distribution shows that the gallbladder diseases have a higher frequency in female than in males (Table 2).

\begin{tabular}{|c|c|c|}
\hline Gender & $\begin{array}{c}\text { No. of } \\
\text { Patients }\end{array}$ & $\begin{array}{c}\text { Percentage } \\
\text { (\%) }\end{array}$ \\
\hline Male & 36 & $32 \%$ \\
\hline Female & 76 & $68 \%$ \\
\hline \multicolumn{2}{|c|}{ Table 2: Sex Incidence } \\
\hline
\end{tabular}

\section{Operative Parameters (Dependent Variables)}

All cases underwent LC with assessment of the difficulties encountered in terms of:

- Duration of surgery (In min): Duration of surgery included the time from insertion of Veress needle to closure of the trocar insertion site and was evaluated as a continuous variable.
- Bleeding during surgery: Bleeding during surgery was graded as minimal, moderate or severe. Moderate bleeding was defined as bleeding leading to tachycardia of greater than $100 / \mathrm{min}$ without drop in blood pressure. Severe bleeding was defined as bleeding leading to tachycardia of greater than $100 / \mathrm{min}$ with a greater than $10 \mathrm{mmHg}$ drop in blood pressure.

- Access to peritoneal cavity: The operating surgeon described the access to peritoneal cavity as 'Easy' or 'Difficult.'

- Gallbladder bed dissection: The operating surgeon described gallbladder bed dissection as 'Easy' or 'Difficult.'

- Difficult extraction: Extension of incision for extraction. The operating surgeon described gallbladder extraction as 'Easy' or 'Difficult.'

- Conversion to open.

\section{Sex and Surgery Outcome}

\begin{tabular}{|c|c|c|c|c|c|}
\hline \multirow{2}{*}{ Sex } & \multirow{2}{*}{$\begin{array}{c}\text { No. of } \\
\text { Patient }\end{array}$} & \multicolumn{3}{|c|}{ SURGERYOUTCME } \\
\cline { 3 - 6 } & & $\begin{array}{c}\text { No. of } \\
\text { Patients }\end{array}$ & $\%$ & $\begin{array}{c}\text { No. of } \\
\text { Patients }\end{array}$ & $\%$ \\
\hline Male & 36 & 31 & $86.1 \%$ & 5 & $13.8 \%$ \\
\hline Female & 76 & 69 & $90.7 \%$ & 7 & $9.3 \%$ \\
\hline \multicolumn{6}{|c|}{ Table 3: Sex and Surgery Outcome } \\
\hline
\end{tabular}

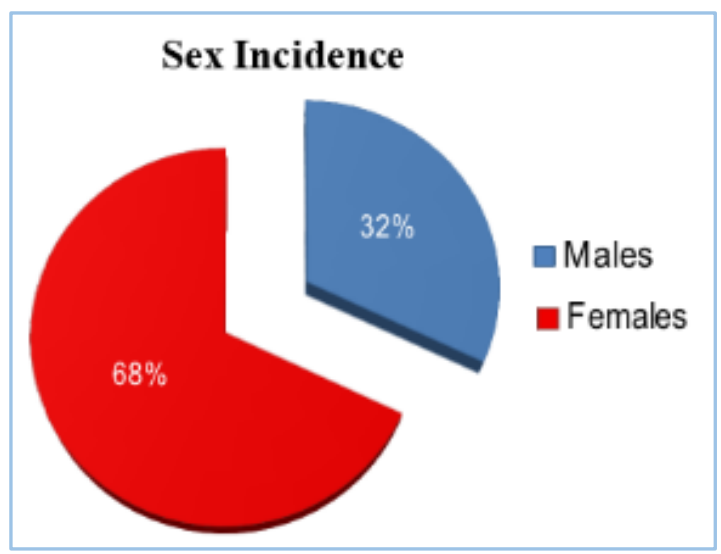

Fig. 2: Graphical representation of sex incidence

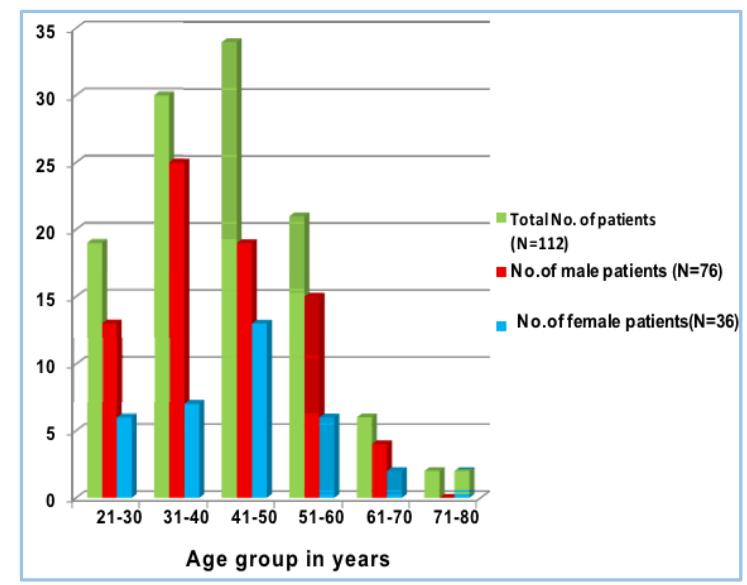

Fig. 3: Graphical representation of age and sex incidence 


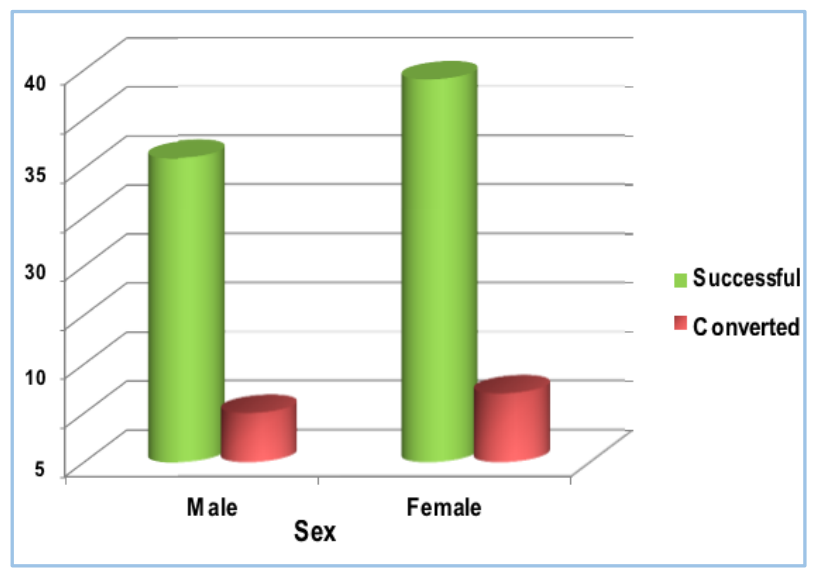

Fig. 4: Graphical representation of sex and surgery outcome

Among a total of 36 male patients 5 were converted $(13.8 \%)$, whereas among 46 female patients 7 were converted (15.2\%) (Figure 4).

\section{Clinical Presentation}

\begin{tabular}{|c|c|c|}
\hline Presentation & $\begin{array}{c}\text { No. of } \\
\text { Cases }\end{array}$ & $\begin{array}{c}\text { Percentage } \\
\text { (\%) }\end{array}$ \\
\hline Epigastric pain & 35 & $31.25 \%$ \\
\hline Right hypochondrium & 77 & $68.75 \%$ \\
\hline \multicolumn{2}{|c|}{ Table 4: Clinical Presentation } \\
\hline
\end{tabular}

Out of 112 patients, 73 patients (65.2\%) had a chief complaint of pain in the right hypochondrium, 35 patients (31.2\%) presented with epigastric pain and the remaining 4 patients (3.5\%) were asymptomatic (Incidental cholelithiasis) (Table 4). Associated symptoms are shown in Table 5.

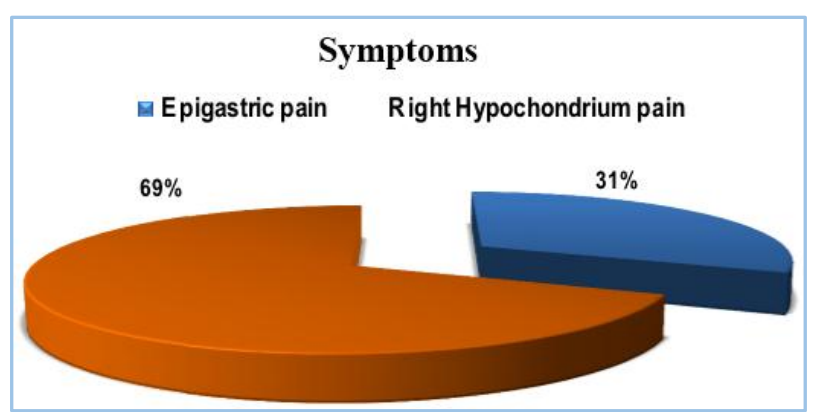

Fig. 5: Graph showing clinical presentation

\section{Associated Symptoms}

\begin{tabular}{|c|c|c|}
\hline Symptoms & $\begin{array}{c}\text { No. of } \\
\text { Cases }\end{array}$ & Percentage (\%) \\
\hline Nausea & 6 & $5.3 \%$ \\
\hline Vomiting & 16 & $14.2 \%$ \\
\hline Nausea+Vomiting & 23 & $20.5 \%$ \\
\hline Jaundice & 10 & $8.9 \%$ \\
\hline \multicolumn{2}{|r|}{ Table 5: Associated Symptoms } \\
\hline
\end{tabular}

Six patients presented with nausea along with pain abdomen and 16 patients presented with vomiting, whereas 23 patients presented with both jaundice was seen in 10 patients (Table 5).

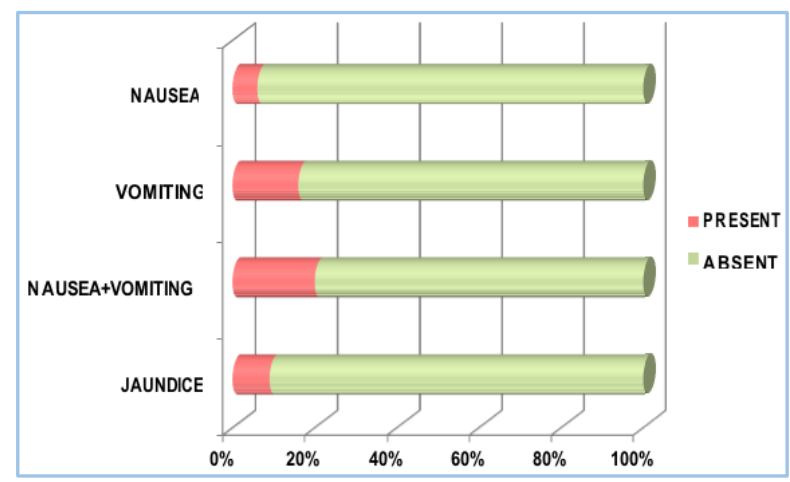

Fig. 6: Graph showing associated symptoms

\begin{tabular}{|c|c|c|}
\hline Comorbidity & $\begin{array}{c}\text { No. of } \\
\text { Patients }\end{array}$ & $\begin{array}{c}\text { Percentage } \\
(\%)\end{array}$ \\
\hline Diabetes Mellitus (DM) & 12 & $8.9 \%$ \\
\hline Hypertension (HTN) & 6 & $5.3 \%$ \\
\hline Ischemic Heart & 1 & $1 \%$ \\
\hline Epilepsy & 1 & $1 \%$ \\
\hline Bronchial Asthma & 1 & $1 \%$ \\
\hline
\end{tabular}

Among these patients $9 \%$ of patients suffered from Diabetes mellitus, whereas $5 \%$ of patients were hypertensive patients (Table 6).

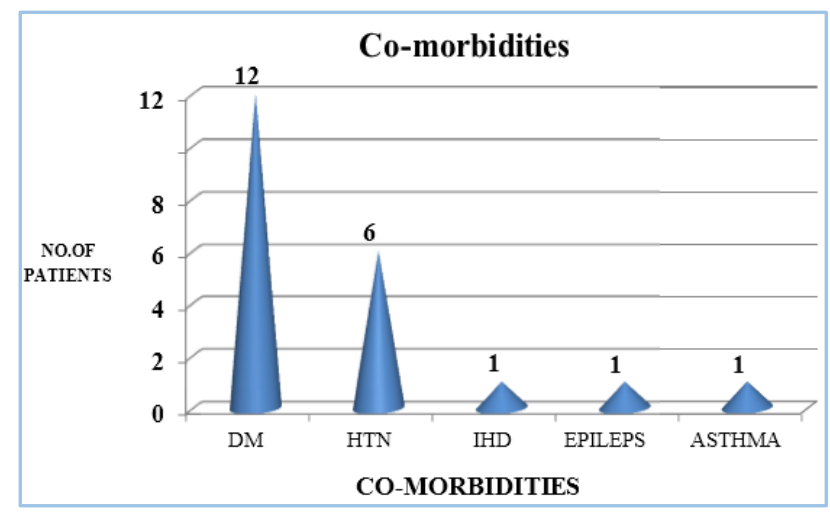

Fig. 7: Graph showing comorbidities

\section{Conversion among Diabetic Patients}

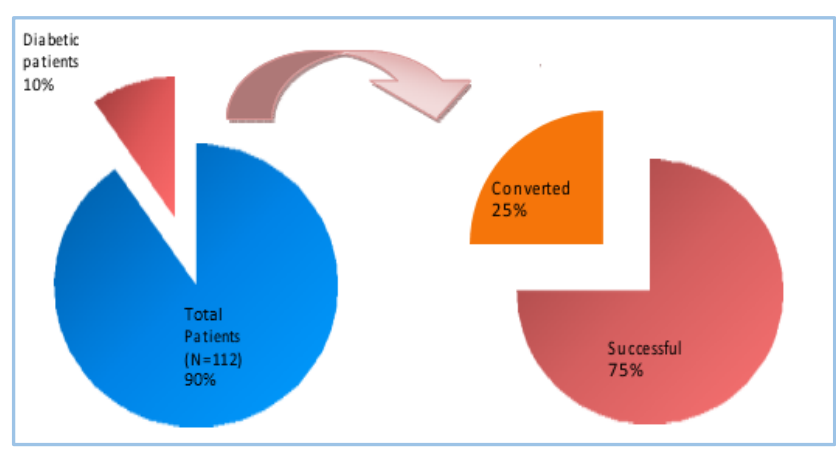

Fig. 8: Graphical representation of Conversion among diabetic patients

Out of total 12 patients who were diabetic, 3 patients underwent conversion (25\%) (Figure 8). 


\section{Conversion among Hypertensive Patients}

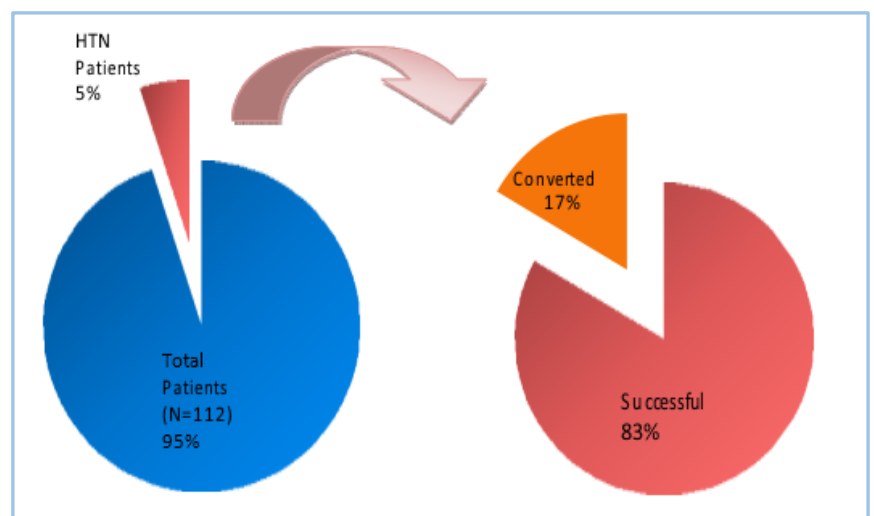

Fig. 9: Graphical representation of Conversion among hypertensive patients

Out of total 6 patients who were hypertensive, 1 patient underwent conversion (16\%) (Figure 9).

\section{Ultrasound Findings}

\begin{tabular}{|c|c|c|}
\hline USG Finding & No. of Cases & Percentage (\%) \\
\hline Single calculi & 72 & $64.2 \%$ \\
\hline Multiple calculi & 40 & $35.7 \%$ \\
\hline Peri-cholecyctic fluid & 20 & $16.9 \%$ \\
\hline GB Wall thickening & 22 & $19.6 \%$ \\
\hline \multicolumn{2}{|c|}{ Table 7: Ultrasound findings } \\
\hline
\end{tabular}

On ultrasound single calculi were noted in 72 patients, whereas remaining 40 patients presented with multiple calculi. Peri-cholecystic fluid and gallbladder wall thickening was noted in 22 patients (Table 7) and Figure 10.

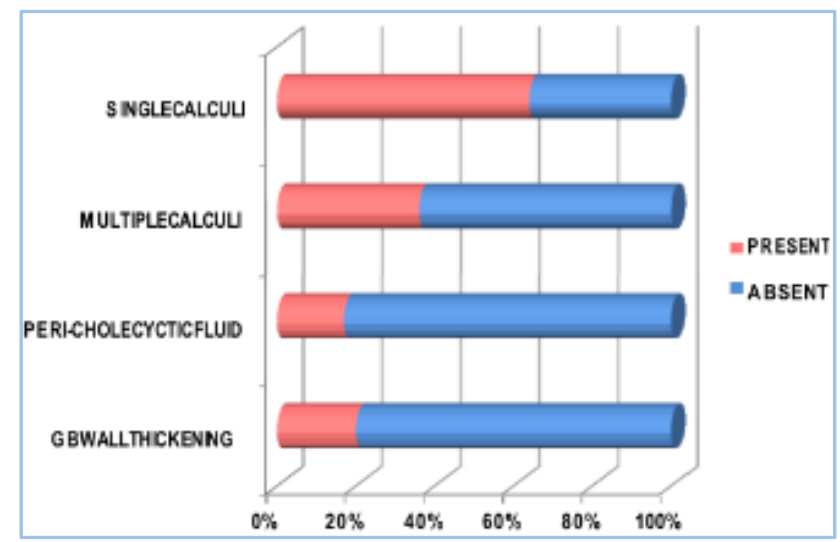

Fig. 10: Graph showing ultrasound findings

Conversion in Patients with Single Calculi

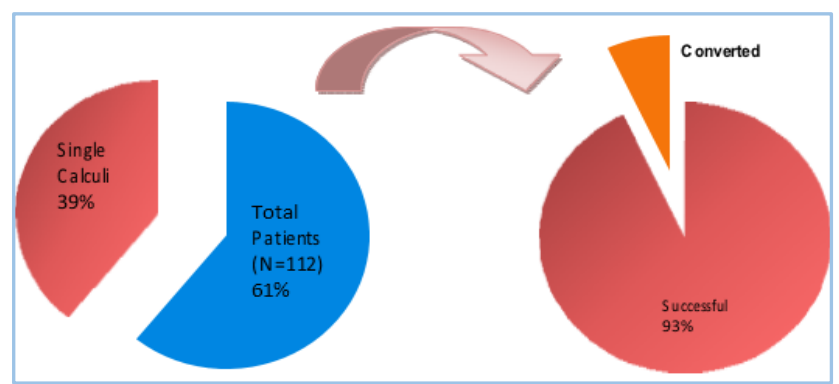

Fig. 11: Graphical representation of conversion in Patients with single calculi
Out of total 72 patients who had single calculi, 5 patients underwent conversion (6.9\%). (Figure 11).

\section{Conversion in Patients with Multiple Calculi}

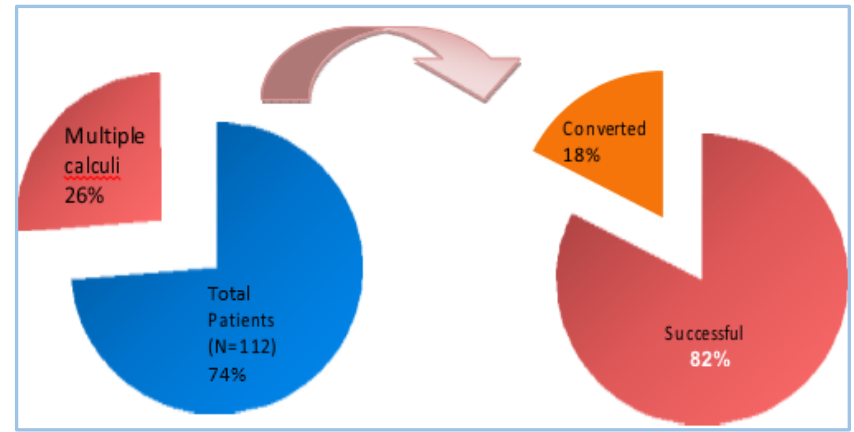

Fig. 12: Graphical representation of Conversion in patients with multiple calculi

Out of total 40 patients who had multiple calculi, 7 patients underwent conversion (17.5\%) (Figure 12).

\section{Conversion in Patients with Peri-Cholecystic Fluid}

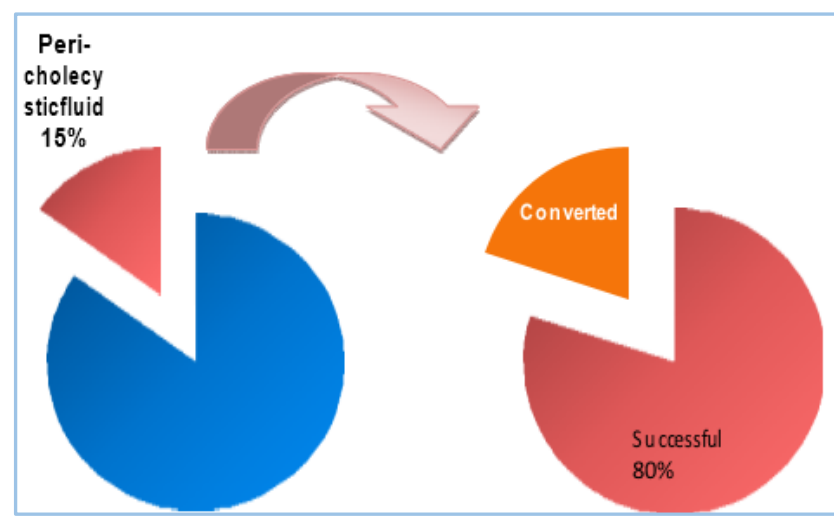

Fig. 13: Graphical representation of conversion in patients with peri-cholecystic fluid

Out of 20 patients who had peri-cholecystic fluid, 4 patients underwent conversion (20\%) (Figure 13).

\section{Conversion in Patients with Gb Wall Thickening}

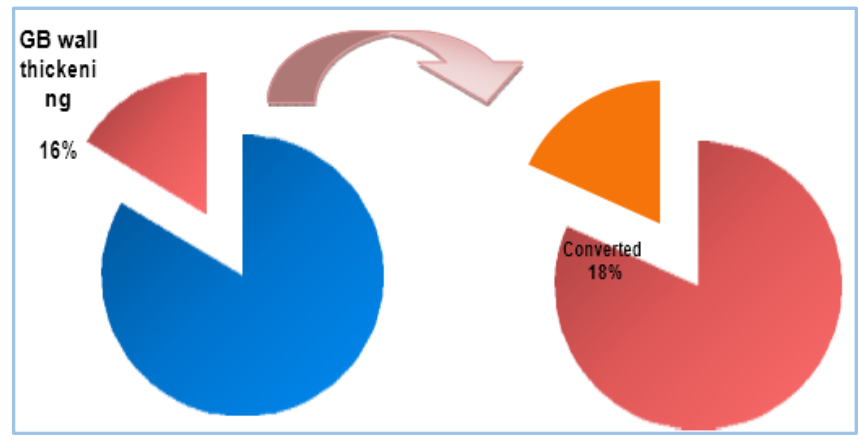

Fig. 14: Graphical representation of conversion in patients with $G B$ wall thickening

Out of 22 patients who had thickened GB wall, 4 patients underwent conversion (18.1\%) (Figure 14). 
Pre-operative Diagnosis and Surgery Outcome

\begin{tabular}{|c|c|c|c|c|c|}
\hline \multirow{2}{*}{ Indication } & \multirow{2}{*}{$\begin{array}{c}\text { Total } \\
\text { no. } \\
\text { Cases }\end{array}$} & \multicolumn{2}{|c|}{$\begin{array}{c}\text { No. of } \\
\text { Cases }\end{array}$} & \multicolumn{2}{c|}{ Percentage } \\
\cline { 3 - 6 } & ful & $\begin{array}{c}\text { Conver } \\
\text {-ted }\end{array}$ & $\begin{array}{c}\text { Success } \\
\text {-ful }\end{array}$ & Converted \\
\hline $\begin{array}{c}\text { Cholelith } \\
\text {-iasis }\end{array}$ & 94 & 85 & 9 & $\begin{array}{c}90.4 \\
\%\end{array}$ & $9.5 \%$ \\
\hline $\begin{array}{c}\text { Acute } \\
\text { cholecyst } \\
\text { itis }\end{array}$ & 18 & 15 & 3 & $\begin{array}{c}83.3 \\
\%\end{array}$ & $16.6 \%$ \\
\hline \multicolumn{5}{|c|}{ Table 8: Pre-operative diagnosis } \\
\hline
\end{tabular}

Out of 112 patients, 94 patients presented with a diagnosis of Cholelithiasis of which 9 cases were converted (9.5\%) and 18 patients presented with acute cholecystitis of which 3 underwent conversion (16.6\%) (Table 8).

\section{Duration of Surgery}

\begin{tabular}{|c|c|c|}
\hline $\begin{array}{c}\text { Duration of } \\
\text { Surgery }\end{array}$ & $\begin{array}{c}\text { No. of } \\
\text { Cases }\end{array}$ & $\begin{array}{c}\text { Percentage } \\
\text { (\%) }\end{array}$ \\
\hline Less than 70min & 25 & $22.3 \%$ \\
\hline 70 to 110min & 76 & $67.8 \%$ \\
\hline More than 110min & 11 & $9.8 \%$ \\
\hline \multicolumn{2}{|c|}{ Table 9: Duration of surgery } \\
\hline
\end{tabular}

The average duration of surgery was $81.7 \mathrm{~min}$.

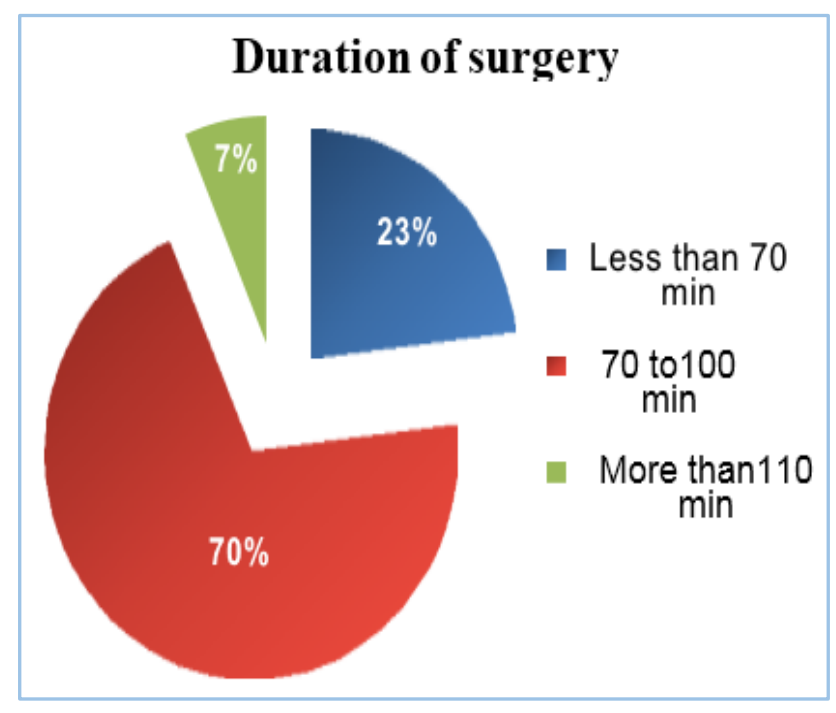

Fig. 15: Graphical representation of duration of surgery

\section{DURATION OF POST-OPERATIVE HOSPITAL STAY}

\begin{tabular}{|c|c|c|}
\hline $\begin{array}{c}\text { Duration of Post-operative } \\
\text { Hospital Stay }\end{array}$ & $\begin{array}{c}\text { No. of } \\
\text { Cases }\end{array}$ & $\begin{array}{c}\text { Percentage } \\
\text { (\%) }\end{array}$ \\
\hline Up to 3 days & 65 & $58.0 \%$ \\
\hline $4-5$ days & 38 & $34.0 \%$ \\
\hline 6 days and more & 9 & $8.0 \%$ \\
\hline Table 10: Duration of post-operative hospital stay \\
\hline
\end{tabular}

\begin{tabular}{|l|l|l|}
\hline $\begin{array}{l}\text { Duration of Post-operative } \\
\text { Hospital Stay }\end{array}$ & $\begin{array}{l}\text { No. of } \\
\text { Cases }\end{array}$ & $\begin{array}{l}\text { Percentage } \\
\text { (\%) }\end{array}$ \\
\hline Upto 3 days & 65 & $58.0 \%$ \\
\hline $4-5$ days & 38 & $34.0 \%$ \\
\hline 6 days and more & 9 & $8.0 \%$ \\
\hline Table 10: Duration of post-operative hospital stay \\
\hline
\end{tabular}

The average duration of post-operative hospital stay was 3.6 days; 65 patients were discharged by 3 days postoperatively, 38 patients stayed for 4-5 days and the remaining 9 patients stayed for more than 6 days. Average duration of post-op stay in successful cases was 3.37 days and in converted cases it was 5.75 days (Table 10).

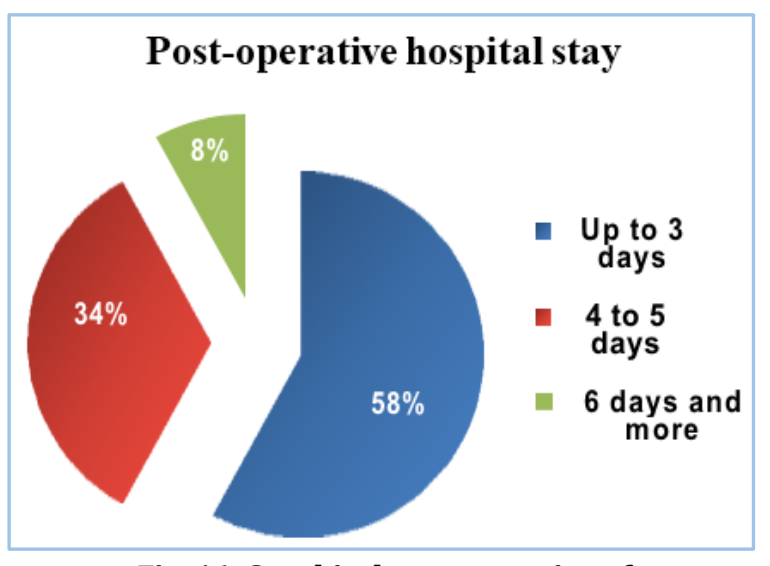

Fig. 16: Graphical representation of post-operative hospital stay

\section{REASONS FOR CONVERSION}

Total laparoscopic cholecystectomies performed-112, Total cases converted to open procedure - $12(10.7 \%)$

\begin{tabular}{|c|c|c|}
\hline Reason for Conversion & $\begin{array}{l}\text { No. of } \\
\text { Cases }\end{array}$ & $\%$ \\
\hline $\begin{array}{l}\text { Difficult anatomy due to: } \\
\text { - Dense adhesions of Calot's } \\
\text { triangle } \\
\text { - Anatomical variation }\end{array}$ & $\begin{array}{l}6 \\
1\end{array}$ & $\begin{array}{ll}50 \% & \mathbf{5 8 . 3} \% \\
8.3 \% & \end{array}$ \\
\hline $\begin{array}{c}\text { Bleeding from: } \\
\text { - Calot's triangle (Cystic artery) } \\
\text { - Injury to right gastric artery }\end{array}$ & 1 & $\left.\begin{array}{ll}16.6 \% & \mathbf{2 4 . 9 \%} \\
& \\
8.3 \% & \end{array}\right\}$ \\
\hline Common bile duct injury & 2 & $16.6 \%$ \\
\hline Table 11: Reasons & cont & sion \\
\hline
\end{tabular}

\section{DISCUSSION}

In the perspective of LC being the standard treatment of symptomatic cholelithiasis, preoperative prediction of the risk of conversion is an important aspect in the planning for laparoscopic surgery. Several studies have been published in the past years trying to assess risk factors for difficult LC. $(6,7,8)$ 
The clinical profile of a patient can predict a difficult gallbladder surgery.

Conversion to open surgery is an indication of sound judgment of the surgeon in view of safety of the patient. Age is recognized as a risk factor of conversion. $(9,10,11,12,13,14,15,16)$ We and some other authors did not notice age to be associated with conversion rate.(11,12) This varied opinion could be attributed to surgeon's experience and expertise. A 4.5\% female and $6.3 \%$ male patients underwent conversion to open. Lien and Huang concluded that male gender is a risk factor for severe symptomatic cholelithiasis. ${ }^{(9)}$ in abdominal surgery has also been associated with a higher likelihood of conversion in numerous studies. ${ }^{(7,8)}$

Most reports on conversion rates, however, have been published from highly specialized centers with extensive and special expertise in laparoscopic surgery. $(9,13,17,18)$ General surgical practice might have somewhat less favorable results. ${ }^{(5,6)}$ Conversion was especially high in patients with acute cholecystitis (47\%). In comparison to other studies in India and western countries, the reason of conversion is same. Dense adhesions at the Calot's triangle and acute cholecystitis are two of the most important reasons for conversion to open procedure, as shown in the present study, Alsalamah et al. Ibrahim and Bingener showed more than half of the converted cases were due to adhesion.[6,15] Dense adhesions at Calot's triangle signified chronic inflammation and were certainly due to the repeated attacks of inflammations in the area or due to previous intra-abdominal pathology or surgery.

Conversion remains in these circumstances a possible outcome of laparoscopic gallbladder surgery, it should be carried out bravely whenever surgeon feels that the field is unwell and it is not a matter of challenge to surgeon glory. Failure to identify the anatomy is the commonest cause of conversion, which might be either due to inflammatory process which disturbed Calot's triangle or anatomical variations or adhesion due to previous surgery.[15] as found in our study.

\section{CONCLUSION}

It can be concluded that LC is the gold standard for the management of gall stone disease. With the advancement in equipment and gaining experiences in laparoscopy, most of the difficult gallbladder can be dealt laparoscopically. Preoperative risk factors can help to predict difficult gallbladder and conversion to $\mathrm{OC}$. Male gender, single large stone, thick-walled gallbladder, previous abdominal surgery and contracted gallbladder are the factors that proved to be significant in our study. These factors can predict difficulty to be encountered during surgery and help in making a decision for conversion thus shortening the duration of surgery and preventing unnecessary complications.

\section{REFERENCES}

1. Gallstones and laparoscopic cholecystectomy. NIH consensus statement online 1992;10:1-20.

2. Livingston $\mathrm{EH}$, Rege RV. A nationwide study of conversion from laparoscopic to open cholecystectomy. Am J Surg 2004;188:205-211 [PubMed].

3. Liu CL, Fan ST, Lai EC, et al. Factors affecting conversion of laparoscopic cholecystectomy to open surgery. Arch Surg 1996;131:98-101 [PubMed].
4. Tang B, Cuschieri A. Conversions during laparoscopic cholecystectomy: risk factors and effects on patient outcome. J Gastrointest Surg 2006;10:1081-1091 [PubMed].

5. Ibrahim S, Hean TK, Ho LS, Ravintharan T, Chye TN, Chee $\mathrm{CH}$. Risk factors for conversion to open surgery in patients undergoing laparoscopic cholecystectomy. World J Surg 2006;30:1698-1704 [PubMed].

6. Habib FA, Kolachalam RB, Khilnani R, et al. Role of laparoscopic cholecystectomy in the management of gangrenous cholecystitis. Am J Surg 2001 Jan; 181(1):715.

7. Angrisani L, Lorenzo M, De Palma G, Sivero L, Catanzano C, Tesauro B. Laparoscopic cholecystectomy in obese patients compared with non-obese patients. Surg Laparosc Endosc 1995 Jun; 5(3):197-9.

8. Kama NA, Kologlu M, Doganay M, Reis E, Atli M, Dolapci M. A risk score for conversion from laparoscopic to open cholecystectomy. Am J Surg 2001 Jun; 181(6):520-5.

9. Fried GM, Barkun JS, Sigman HH, Joseph L, Clas D, Garzon J. Factors determining conversion to laparotomy in patients undergoing laparoscopic cholecystectomy. Am J Surg 1994 Jan; 167(1):35-41.

10. Sanabria JR, Gallinger S, Croxford R, et al. Risk factors in elective laparoscopic cholecystectomy for conversion to open cholecystectomy. J Am Coll Surg 1994 Dec; 179(6):696-704.

11. Jansen S, Jorgensen J, Caplehorn J, et al. Preoperative ultrasound to predict conversions in laparoscopic cholecystectomy. Surg Laparosc Endosc 1997 Apr; $7(2): 121-3$.

12. Brodsky A, Matter I, Sabo E, Cohen A, Abrahamson J, Eldar S. Laparoscopic cholecystectomy for acute cholecystitis: can the need for conversion and the probability of complications be predicted? A prospective study. Surg Endosc 2000 Aug; 14(8):755-60.

13. Bedirli A, Sakrak O, Sözüer EM, et al. Factors effecting the complications in the natural history of acute cholecystitis. Hepatogastroenterology 2001 Sep-Oct; 48(41):1275-8.

14. Brunt LM, Quasebarth MA, Dunnegan DL, et al. Outcome and analysis of laparoscopic cholecystectomy in the extremely elderly. Surg Endosc 2001 Jul; 15(7):700-5.

15. Nachnani J, Supe A. Preoperative prediction of difficult laparoscopic cholecystectomy using clinical and ultrasonographic parameters. Indian J Gastroenterol 2005 Jan-Feb; 24(1):16-8.

16. Ibrahim S, Hean TK, Ho LS, Ravintharan T, Chye TN, Chee $\mathrm{CH}$. Risk factors for conversion to open surgery in patients undergoing laparoscopic cholecystectomy. World J Surg 2006 Sep; 30(9):1698-704.

17. Karayiannakis AJ, Polychronidis A, Perente S, et al. Laparoscopic cholecystectomy in patients with previous upper or lower abdominal surgery. Surg Endosc. 2004;18:97-101 [PubMed].

18. Rosen M, Brody F, Ponsky J: Predictive factors for conversion of laparoscopic cholecystectomy. Am J Surg 2002;184:254-258, 05. 